MICHAŁ ROMANOWSKI

KATARZYNA ZARZYCKA

https://doi.org/10.33995/wu2020.3.1

\title{
Ocena kryteriów przyjętych przez Komisję Nadzoru Finansowego w Metodyce oceny odpowiedniości członków organów podmiotów nadzorowanych z 2020 roku
}

Przedstawiona przez Komisję Nadzoru Finansowego Metodyka oceny odpowiedniości członków organów podmiotów nadzorowanych miała prezentować obiektywne kryteria oceny, oparte na regulacjach prawnych, którymi kieruja się Komisja Nadzoru Finansowego oraz Urzq̨d Komisji Nadzoru Finansowego. Liczba kryteriów oraz ich subiektywny, ocenny, a wręcz arbitralny i niemierzalny charakter, powodujq, iż Metodyka może stać się w praktyce fikcja oraz instrumentem nieprzydatnym dla rzetelnej oceny kandydata na członka organów instytucji finansowej. Istnieje ryzyko, że rady nadzorcze lub akcjonariusze będq udawać, że stosujq w praktyce Metodykę, a KNF będzie udawać, że jest w stanie zweryfikować tak przeprowadzonq ocenę kandydata. Metodyka nie dostarcza bowiem jednoznacznych i mierzalnych wytycznych profilu kandydata, które pomogłyby przewidzieć, czy uzyska on akceptację nadzorcy. Metodyka bardziej przypomina wymagania przygotowywane przez tzw. headhuntera czy dział HR (o mocno zróżnicowanej i często watpliwej przydatności) niż kryteria dla oceny prawnej, czy kandydat gwarantuje ostrożne i stabilne zarzqdzanie instytucja finansowq. W praktyce rady nadzorcze i akcjonariusze mogq utracić na rzecz KNF kontrolę nad doborem kandydatów optymalnych z punktu widzenia właścicielskiego. Metodyka wprowadza bowiem kryteria akceptacji oparte na dowolności nadzorcy, a nie na uznaniowości poddajqcej się kontroli sqdowej. Narusza to konstytucyjnq zasadę wolności gospodarczej. Ponadto analiza postanowień Metodyki prowadzi do wniosku, że niektóre z kryteriów stoja w sprzeczności z konstytucyjnymi prawami i wolnościami człowieka. Sprzeczności te nie znajdujq uzasadnienia w zasadzie proporcjonalności. Oznacza to, zdaniem autorów, że Metodyka narusza zasady legalizmu i praworzqdności. 
Słowa kluczowe: Metodyka oceny odpowiedniości członków organów podmiotów nadzorowanych, rękojmia prowadzenia spraw zakładu w sposób należyty, uznanie administracyjne a dowolność, zasada praworządności, zasada legalizmu.

\section{Wstęp}

W dniu 27 stycznia 2020 roku Przewodniczący Komisji Nadzoru Finansowego (dalej: KNF) skierował do Rad Nadzorczych oraz Zarządów banków, jednostek zarządzających systemami ochrony instytucjonalnej, zakładów ubezpieczeń i reasekuracji, towarzystw emerytalnych oraz domów maklerskich pismo ${ }^{1}$, w którym przekazał wskazanym podmiotom do korzystania Metodykę oceny odpowiedniości członków organów podmiotów nadzorowanych (dalej: Metodyka) wraz z zestawem formularzy i wzorcowymi procesami oceny?

Jak zauważył Przewodniczący KNF w piśmie przewodnim: „Prawidłowe przeprowadzanie procesu oceny odpowiedniości członków organów zarządzających oraz nadzorujących w podmiotach rynku finansowego jest kluczowym elementem zdrowego ładu korporacyjnego i realnego ukształtowania poziomu kompetencji i odpowiedzialności. Osoby mające wpływ na sposób prowadzenia regulowanej działalności finansowej muszą być zdolne do codziennego podejmowania należytych i ostrożnych decyzji zapewniających stabilność i bezpieczny rozwój zarządzanych przez nich podmiotów. Z tego względu osoby te muszą spełniać kryteria odpowiedniości i podlegać regularnemu procesowi oceny".

Zgodnie ze wstępem do Metodyki „[d]okument prezentuje obiektywne kryteria oceny, oparte na regulacjach prawnych, którymi kierują się Komisja Nadzoru Finansowego oraz Urząd Komisji Nadzoru Finansowego". Przedstawione w Metodyce wymogi powinny być uwzględniane w wewnętrznych procesach oceny odpowiedniości przeprowadzanych przez podmioty nadzorowane w zakresie pierwotnej oceny kandydatów na członków organów, wtórnej oceny członków organów oraz zbiorowej oceny organów.

Jako jeden z celów publikacji Metodyki Przewodniczący KNF wskazał „zwiększenie transparentności i przewidywalności procesu oceny, w ramach którego decyzje podejmowane są na podstawie jednakowych, znanych i zrozumiałych dla rynku zasad". W broszurze informacyjnej ${ }^{3} \mathrm{KNF}$ wskazał, jakie korzyści w ocenie organu Metodyka niesie dla rynku. Zdaniem KNF Metodyka:

1) wspiera rozwój kompetencji członków organów podmiotów nadzorowanych;

2) akcentuje znaczenie odpowiedzialności członków organów podmiotów nadzorowanych;

3) prezentuje jednakowe i jasne „reguły gry” (level playing field);

4) zwiększa transparentność i przewidywalność procesu oceny.

Wymieniając korzyści płynące dla podmiotów nadzorowanych, KNF wskazał, że Metodyka:

1. Pismo Przewodniczącego KNF Jacka Jastrzębskiego z dnia 27 stycznia 2020 r. skierowane do Rad Nadzorczych i Zarządów podmiotów objętych Metodyka, https://www.knf.gov.pl/knf/pl/komponenty/img/Pismo Przewodniczacego do podmiotow nadzorowanych 68736.pdf [dostęp: 2.10.2020].

2. Metodyka oceny odpowiedniości członków organów podmiotów nadzorowanych wraz z załącznikami, https:// www.knf.gov.pl/dla rynku/metodyka_oceny_odpowiedniosci czlonkow organow podmiotow nadzorowanych/ metodyka [dostęp: 2.10.2020].

3. Broszura informacyjna o Metodyce, https://www.knf.gov.pl/dla rynku/metodyka oceny_odpowiedniosci czlonkow organow podmiotow nadzorowanych/broszura [dostęp: 2.10.2020]. 
1) systematyzuje obowiązujące wymogi;

2) daje narzędzia wspierające proces oceny;

3) ułatwia komunikację z nadzorem;

4) wzmacnia świadomość decyzji kadrowych.

Celem niniejszego artykułu jest krytyczna analiza kryteriów oceny odpowiedniości członków organów podmiotów nadzorowanych przedstawionych w Metodyce, ze szczególnym uwzględnieniem uwarunkowań sektora ubezpieczeniowego.

\section{Zasada legalizmu i praworządności}

KNF jest organem administracji publicznej (centralnej), podlegającym Prezesowi Rady Ministrów ${ }^{4}$, wykonującym nadzór instytucjonalny ${ }^{5}$ i zintegrowany ${ }^{6}$ nad całym rynkiem finansowym? ${ }^{7}$. Celem funkcji nadzorczej KNF jest zapewnienie legalności działań podmiotów podlegajacych nadzorowi, tj. podmiotów administrowanych ${ }^{8}$. Tym samym wszelkie działania KNF, będącego „emanacja Państwa”, muszą pozostawać w zgodności z Konstytucją RP9 i zasadami z niej wynikającymi.

Zgodnie z art. 7 Konstytucji RP organy władzy publicznej działaja na podstawie i w granicach prawa. Na podstawie przywołanego artykułu można wyodrębnić dwie zasady działania organów administracji publicznej:

- zasadę legalizmu, która oznacza, że każde działanie powinno posiadać podstawę prawną, a więc powinno być oparte na normie ustawowej, upoważniającej do jego podjęcia w określo-

nej formie i w określonych warunkach;

- praworządności, która oznacza, że każde działanie mieści się w granicach prawa, a więc nie może być sprzeczne z jakimkolwiek elementem porządku prawnego.

Innymi słowy, zasady wynikające z art. $?$ Konstytucji RP kreują nakaz czynienia przez organy administracji publicznej jedynie tego, na co pozwala obowiązujące prawo.

Wyodrębnione zasady legalizmu i praworządności wywodzą się wprost z zasady demokratycznego państwa prawnego, która wynika z art. 2 Konstytucji RP. Podstawowym założeniem tej zasady jest przyznanie prymatu prawa („rządy prawa, a nie rządy ludzi”) oraz obowiazek poszanowania przez „władze”, w tym organy administracji publicznej, praw i wolności obywateli. Zasada demokratycznego państwa prawnego ma na celu wykluczenie wszelkiej arbitralności działania organów władzy publicznej w interesie wolności jednostki. Gwarancje realizacji zasady demokratycznego państwa prawnego, a tym samym również zasady legalizmu oraz zasady praworządności, stanowią

4. Por. wyrok TK z dnia 15 czerwca 2011 r., K 2/09, OTK-A 2011, Nr 5, poz. 42.

5. H. Gronkiewicz-Waltz, Ewolucja pozycji banku centralnego w świetle zmian w prawie bankowym, „Państwo i Prawo" 1990, nr 6, s. 39.

6. T. Nieborak, Komisja Nadzoru Finansowego jako gwarant stabilności polskiego systemu finansowego, [w:] Prawo wobec wyzwań współczesności. Tom 5, [red.] B. Guzik, N. Buchowska, P. Wiliński, Wydawnictwo Uniwersytetu im. Adama Mickiewicza, Poznań 2008, s. 360.

7. Por. art. 3 ust. 3 ustawy z dnia 21 lipca 2006 r. o nadzorze nad rynkiem finansowym (tekst jedn. Dz. U. 2020, poz. 180 z późn. zm.).

8. K. Jaroszyński, [w:] C. Banasiński, K. Glibowski, H. Gronkiewicz-Waltz, K. Jaroszyński, R. Kaszubski, M. Wierzbowski, Prawo gospodarcze. Zagadnienia administracyjnoprawne, LexisNexis, Warszawa 2013, s. 200.

9. Konstytucja Rzeczypospolitej Polskiej z dnia 2 kwietnia 1997 r. (Dz. U. nr 78, poz. 483 z późn. zm.). 
rozwiązania proceduralne kreujące formy kontroli administracji pod kątem legalności (zgodności z prawem), w tym w szczególności w postaci sądowej kontroli administracji ${ }^{10}$.

Weryfikacja danego działania organu administracji publicznej pod kątem zgodności z zasada praworządności sprowadza się do porównania treści tego działania z obowiązującym porządkiem prawnym. Ocena działania organu administracji publicznej z perspektywy zasady legalizmu polega na udzieleniu odpowiedzi na pytanie, czy istnieje norma prawna upoważniająca organ do podjęcia danego działania. W kontekście weryfikacji zgodności działania organu administracji publicznej z zasadą legalizmu wyjaśnienia wymaga pojęcie „działania” organu administracji publicznej. Cechą administracji publicznej jest jej „wielka aktywność” ${ }^{11}$, co oznacza, iż formy działania administracji, w tym formy działania organów administracji publicznej, są zróżnicowane.

Istnieje wiele możliwości klasyfikacji form działania administracji. Na potrzeby niniejszej analizy kluczowe, a zarazem wystarczające, jest wskazanie, że działanie organu administracji publicznej w rozumieniu zasady legalizmu może polegać na (i) stosowaniu prawa, (ii) stanowieniu prawa oraz (iii) organizowaniu życia społecznego. Działania społeczno-organizatorskie organu administracji publicznej nie moga być obwarowane przymusem państwowym. Innymi słowy, nie mogą one przybierać charakteru władczego. Zasadą legalizmu organy administracji są związane zawsze niezależne od tego, na czym polega ich działanie ${ }^{12}$, podobnie jak zasadą praworządności. Innymi słowy, niezależnie od formy działania zawsze musi istnieć podstawa prawna dla jego podjęcia.

Podsumowując, zasady legalizmu oraz praworządności służą temu, aby każdy, kto miał władcze możliwości ingerencji w sytuację prawną drugiej osoby, zrobił z tego pozytywny użytek, nie naruszając prawa. Jednakże, zgodnie z zasadą proporcjonalności, nadmierna ingerencja nie jest dozwolona. Nawet wtedy, gdy dokonywana jest w dobrej wierze.

\section{Uznanie administracyjne KNF i jego granice}

Jednym z uprawnień Komisji Nadzoru Finansowego w ramach nadzoru w odniesieniu do zakładów ubezpieczeń jest wyrażenie zgody na powołanie dwóch członków zarządu krajowego zakładu ubezpieczeń lub krajowego zakładu reasekuracji, w tym prezesa zarządu oraz członka zarządu odpowiedzialnego za obszar zarządzania ryzykiem (art. 51 ust. 1 ustawy o działalności ubezpieczeniowej i reasekuracyjnej, dalej: u.dz.u.r. ${ }^{13}$ ). Środek ten stanowi wyjątek od ogólnej zasady prawa prywatnego, odnośnie do swobody w kształtowaniu składu osobowego organów spółki kapitałowej ${ }^{14}$. Dodatkowo zakład ubezpieczeń oraz zakład reasekuracji mają obowiązek informować KNF o zmianach w składzie zarządu lub rady nadzorczej w terminie $?$ dni od dnia podjęcia uchwały o powołaniu

10. J. Zimmermann, Prawo administracyjne, Wolters Kluwer, Warszawa 2012, s. 62.

11. Ibidem, s. 289.

12. Ibidem, s. 63.

13. Ustawa z dnia 11 września 2015 r. o działalności ubezpieczeniowej i reasekuracyjnej (tekst jedn. Dz. U. 2020, poz. 895 z późn. zm.).

14. P. Wajda, Zgoda Komisji Nadzoru Finansowego na powołanie dwóch członków zarzqdu krajowego zakładu ubezpieczeń lub krajowego zakładu reasekuracji - wybrane aspekty, „Wiadomości Ubezpieczeniowe” 2016, nr 1, s. 82 . 
lub odwołaniu członka zarządu lub członka rady nadzorczej, a także powzięcia informacji o innym zdarzeniu powodujacym zmianę składu zarządu lub rady nadzorczej (art. 49 ust. 1 u.dz.u.r.).

Zgodnie z wymaganiami określonymi w art. 48 ust. 1 u.dz.u.r. członkiem zarzadu zakładu ubezpieczeń lub zakładu reasekuracji może być osoba, która spełnia łącznie następujące wymagania: (i) posiada pełną zdolność do czynności prawnych; (ii) posiada wyższe wykształcenie uzyskane w Rzeczpospolitej Polskiej lub uzyskane w innym państwie wykształcenie będące wykształceniem wyższym w rozumieniu właściwych przepisów tego państwa; (iii) nie była skazana za umyślne przestępstwo lub umyślne przestępstwo skarbowe prawomocnym wyrokiem sądu; (iv) daje rękojmię prowadzenia spraw zakładu w sposób należyty. Kryteria określone w pkt. (i) i (ii) oraz dodatkowo wymóg rękojmi należytego wykonywania funkcji/zadań dotyczą także członków rady nadzorczej zakładów ubezpieczeń lub reasekuracji. Gdy członek organu przestaje spełniać określone w ustawie wymagania, KNF może w drodze decyzji stwierdzić niespełnienie przez niego wymagań dotyczących pełnienia funkcji (art. 52 ust. 1 u.dz.u.r.). Z dniem doręczenia takiej decyzji akt powołania członka organu nie wywołuje skutków prawnych, a jego mandat wygasa (art. 52 ust. 2 u.dz.u.r.).

Oceniając przesłankę dawania rękojmi prowadzenia spraw zakładu w sposób należyty oraz ustalając kryteria jej spełnienia, KNF działa w ramach uznania administracyjnego. Nie oznacza to jednak, że KNF ma pełną swobodę i dowolność w tym zakresie. Czym innym jest bowiem dowolność, a czym innym uznanie administracyjne, które podlega kontroli sądowej ${ }^{15}$.Zgodnie z zasadą legalizmu wydana przez KNF decyzja musi mieć swoją podstawę prawną i musi mieścić się w granicach wyznaczonych przez przepisy prawa. W konsekwencji oznacza to, że kryteria oceny przesłanek przyjęte przez KNF również muszą mieścić się w ramach wyznaczonych przez przepisy prawa.

Jak wskazuje się w doktrynie, obszar uznania administracyjnego nie jest wolny od związania konstytucyjnego i ustawowego, przez co podlega kontroli sąów administracyjnych ${ }^{16}$. Każda władcza możliwość ingerencji w podmiot prywatny musi podlegać kontroli. W celu umożliwienia dokonania kontroli sądowej decyzji uznaniowej niezbędne jest szczegółowe uzasadnienie decyzji, które w sposób jasny i czytelny przedstawi motywy organu administracyjnego, dlatego też tak ważne jest precyzyjne ustalenie obiektywnych kryteriów, na podstawie których wydawana jest decyzja uznaniowa.

Udzielając lub odmawiając zgody na powołanie członka organu zakładu ubezpieczeń (oraz dokonując oceny następczej, w ramach nadzoru następczego], KNF powinna przyjąc jasne i obiektywne kryteria, które pozwolą na kontrolę sfery uznania administracyjnego. W wyroku WSA w Warszawie z dnia 20 kwietnia 2005 roku, sąd stwierdził, że „[z] arzut braku rękojmi należytego prowadzenia spraw w zakładzie ubezpieczeń musi zostać udowodniony, a dowód ten dotyczyć ma konkretnej sprawy i osoby. Wszelkie wnioski o braku rękojmi kandydata na prezesa zarządu zakładu ubezpieczeń oparte na przekonaniach organu, jego obawach lub przewidywaniach należy uznać za dowolne i taki sam charakter będzie miała decyzja uznaniowa organu oparta na dowolnym, tzn. niepopartym dowodami wniosku"1?

15. M. Jaśkowska, Uznanie administracyjne w orzecznictwie sqdów administracyjnych, „Zeszyty Naukowe Sądownictwa Administracyjnego" 2010, nr 5-6, s. 168-184.

16. M. Jaśkowska, [w:] Instytucje prawa administracyjnego. System Prawa Administracyjnego. Tom 1, [red.] R. Hauser, CH Beck, Warszawa 2015, s. 29 ?.

17. Wyrok WSA w Warszawie z 20 kwietnia 2005 r., VI SA/Wa 2112/04, LEX 180435. 
Z punktu widzenia zasady legalności i praworząności oraz podlegania uznania administracyjnego kontroli sądowej kluczową rolę odgrywa określenie granic uznania. Zgodnie z wyrokiem NSA z dnia 20 listopada 1990 roku: „zastosowanie pojęcia nieostrego nie tylko wymaga wskazania jego uwarunkowań zewnętrznych, wynikających z chronionych wartości zawartych w całym systemie prawa (w tym w szczególności w Konstytucji), ale także wymaga wskazania jego uwarunkowań wynikających z wartości i zasad leżących u podstaw aktu normatywnego, w którym zastosowano dane pojęcie nieostre. Dopiero wtedy dokonana ocena szczegółowo ustalonych okoliczności sprawy nie nosi cech dowolności i mieści się w ramach dopuszczalnego stosowania pojęcia nieostrego"18.

W przypadku ustalania granic uznania administracyjnego należy wziać zatem pod uwagę wartości wynikające z całego systemu prawa, a w odniesieniu do działalności KNF należy odwołać się w szczególności do celu nadzoru określonego w ustawach sektorowych. Stosownie do art. 2 ustawy o nadzorze nad rynkiem finansowym celem nadzoru nad rynkiem finansowym jest zapewnienie prawidłowego funkcjonowania tego rynku, jego stabilności, bezpieczeństwa oraz przejrzystości, zaufania do rynku finansowego, a także zapewnienie ochrony interesów uczestników tego rynku również poprzez rzetelną informację dotyczącą funkcjonowania rynku, przez realizację celów określonych m.in. w ustawie o nadzorze ubezpieczeniowym i emerytalnym ${ }^{19}$. Zgodnie $z$ art. 3 ustawy o nadzorze ubezpieczeniowym i emerytalnym: „celem nadzoru jest ochrona interesów osób ubezpieczających, ubezpieczonych, uposażonych lub uprawnionych z umów ubezpieczenia, członków funduszy emerytalnych, uczestników pracowniczych programów emerytalnych, osób otrzymujacych emeryturę kapitałową lub osób przez nie uposażonych". Jednakże wskazane powyżej cele nadzoru nie sa jedyna granicą uznania administracyjnego. Do granic tych należy także zasada proporcjonalności.

Podczas ustalania kryteriów oceny oraz dokonywania samej oceny odpowiedniości członków organów zakładów ubezpieczeń Komisja jest zobligowana do stosowania zasady proporcjonalności (art. $8 \S 1$ k.p.a. ${ }^{20}$ ), tj. przyjmowania kryteriów oceny, które są sprawiedliwe, adekwatne i odpowiadające wymogom celowości, oraz zasady subsydiarności, ale także konieczności efektywnego i najmniej uciążliwego dla otoczenia urzeczywistnienia celów stawianych organowi nadzoru, przy uwzględnieniu interesu społecznego i rozważania słusznego interesu stron (art. 7 k.p.a.). Jak wskazano w pkt. 3.1.3 Metodyki: „zasadę proporcjonalności można streścić w trzech słowach: odpowiedniość, konieczność i proporcjonalność (sensu stricto)”.

Podczas stosowania zasady proporcjonalności z uwzględnieniem celu nadzoru nie należy tracić z pola widzenia faktu, że działalność regulowana ma nadal charakter przede wszystkim biznesowy i ma na celu osiagnięcie zysku. W związku z tym, określając środki nadzoru (w tym kryteria oceny odpowiedniości], KNF powinna wyważyć wartości, do których urzeczywistnienia dąży poprzez nadzór, oraz zasadę wolności działalności gospodarczej - i zastosować środki proporcjonalne.

W konsekwencji powyższych rozważań należy przyjąć, że kryteria oceny członków organów, które przyjmuje KNF, dokonując oceny w ramach uznania administracyjnego, powinny być obiektywne, zgodne z prawem [zasada legalizmu i praworządności), a także powinny służyć realizacji

18. Wyrok NSA z 20 listopada 1990 r., I SA 759/90, OSP 1991, nr 7-8, poz. 178.

19. Ustawa z dnia 22 maja 2003 r. o nadzorze ubezpieczeniowym i emerytalnym (tekst jedn. Dz. U. 2019, poz. 207).

20. Ustawa z dnia 14 czerwca 1960 r. - Kodeks postępowania administracyjnego (tekst jedn. Dz. U. 2020, poz. 256 z późn. zm.]. 
celu nadzoru, o którym mowa w ustawie o nadzorze nad rynkiem finansowym oraz u.dz.u.r. Powinny ponadto uwzględniać zasadę proporcjonalności.

\section{Ocena postanowień Metodyki}

\subsection{Naruszenie prawa do prywatności}

Jednym z podstawowych praw każdego człowieka jest prawo do prywatności. Prawo to jest zagwarantowane w Konstytucji RP (art. 47) oraz w międzynarodowych zbiorach praw człowieka (art. 12 Powszechnej Deklaracji Praw Człowieka ONZ, art. 17 ust. 1 Międzynarodowego Paktu Praw Obywatelskich i Politycznych, art. 8 Konwencji o Ochronie Praw Człowieka i Podstawowych Wolności, art. 7 Karty Praw Podstawowych Unii Europejskiej [dalej: KPP UE]]. Prywatność jest także uznana za jedno z dóbr osobistych chronionych na podstawie art. 23 k.c. ${ }^{21}$

Kolejnym prawem istotnym w kontekście niniejszej analizy jest prawo do ochrony danych osobowych, stanowiące jedno z podstawowych praw człowieka wymienionych w KPP UE (art. 8 ust. 1 KPP UE). Na gruncie krajowym prawo do ochrony danych osobowych jest również prawem zagwarantowanym w Konstytucji RP (art. 51). Zgodnie z art. 51 ust. 1 i 2 Konstytucji RP: „1. Nikt nie może być obowiązany inaczej niż na podstawie ustawy do ujawniania informacji dotyczących jego osoby. 2. Władze publiczne nie moga pozyskiwać, gromadzić i udostępniać innych informacji o obywatelach niż niezbędne w demokratycznym państwie prawnym".

Analizując zagadnienia dotyczące ochrony danych osobowych, należy jednak pamiętać, że istotą regulacji z zakresu ochrony danych osobowych nie jest ochrona danych osobowych samych w sobie (jako niezależnych dóbr), ale ochrona osób fizycznych. Prawo do ochrony danych osobowych jest zatem ściśle powiązane z prawem do ochrony prywatności, ponieważ chroni tę samą wartość konstytucyjną.

Podczas procesu rekrutacji pracodawca żąda od osoby ubiegającej się o zatrudnienie, a następnie od pracownika, podstawowych danych osobowych, takich jak data urodzenia, wykształcenie czy kwalifikacje zawodowe (art. $22^{1} \S 1$ i 3 Kodeksu pracy ${ }^{22}$ ). Pracodawca żąda innych danych osobowych jedynie wtedy, gdy jest to niezbędne do zrealizowania uprawnienia lub spełnienia obowiązku wynikającego z przepisu prawa (art. $22^{1} \S 4$ Kodeksu pracy). W odniesieniu do członków zarządu lub rady nadzorczej zakładu ubezpieczeń lub reasekuracji zakład przekazuje KNF następujące informacje określone w zamkniętym katalogu (art. 49 ust. 4 u.dz.u.r.):

- życiorysy osób mających pełnić kluczowe funkcje;

- zgody osób mających pełnić kluczowe funkcje na objęcie stanowisk w zakładzie ubezpieczeń lub zakładzie reasekuracji;

- poświadczenia posiadania odpowiedniego wykształcenia i doświadczenia zawodowego przez osoby mające pełnić kluczowe funkcje;

- zaświadczenia albo oświadczenia o niekaralności osób mających pełnić kluczowe funkcje;

- oświadczenia osób mających pełnić kluczowe funkcje o toczących się przeciwko nim postępowaniach sądowych w związku ze sprawa gospodarczą;

21. Ustawa z dnia 23 kwietnia 1964 r. - Kodeks cywilny (tekst jedn. Dz. U. 2019, poz. 1145 z późn. zm.).

22. Ustawa z dnia 26 czerwca 1974 r. - Kodeks pracy (tekst jedn. Dz. U. 2020, poz. 1320). 
- oświadczenia osób mających pełnić kluczowe funkcje o uczestnictwie w organach zarządzających i nadzorujących spółek handlowych.

Podstawa prawną do przetwarzania powyższych danych przez KNF jest art. 6 ust. 1 lit. e) $\mathrm{RODO}^{23}$, zgodnie z którym przetwarzanie jest niezbędne do wykonania zadania realizowanego $w$ interesie publicznym lub w ramach sprawowania władzy publicznej powierzonej administratorowi, w związku z art. 4 ust. 1 pkt 2 ustawy o nadzorze nad rynkiem finansowym. Przedstawiony powyżej zamknięty katalog informacji z art. 49 ust. 4 u.dz.u.r. prowadzi do wniosku, że KNF oraz zakład ubezpieczeń nie mogą żądać od kandydata np. informacji o jego sytuacji finansowej (pkt 3.2.1.2.4.1. Metodyki], która należy do wyjątkowo wrażliwej i ocennej sfery, a w efekcie nie moga także przetwarzać takich informacji. Jak zostanie wskazane poniżej, pozyskiwanie informacji o sytuacji finansowej kandydata lub członka organu jest niecelowe, przez co nie spełnia kryterium proporcjonalności przy ograniczeniu prawa do prywatności.

Zarówno prawo do ochrony prywatności, jak i prawo do ochrony danych osobowych nie maja charakteru bezwzględnego i należy je postrzegać w kontekście ich funkcji społecznej i wyważyć względem innych praw podstawowych w myśl zasady proporcjonalności. Prawo do prywatności może wchodzić w konflikt z wartościami takimi, jak interes publiczny, bezpieczeństwo państwa, bezpieczeństwo obrotu gospodarczego czy prawo do informacji. Jednakże w przypadku zaistnienia konfliktu prawa do prywatności z innymi wartościami, potencjalne ograniczenia praw muszą być proporcjonalne, a ewentualne wạtpliwości rozstrzygane na rzecz prawa do prywatności.

Należy uznać, że niektóre z postanowień Metodyki narzucają zakładom ubezpieczeń zbyt daleko idącą ingerencję w prywatność osoby fizycznej, która nie jest uzasadniona. W konsekwencji, takie ograniczenie prawa do prywatności nie spełnia kryterium proporcjonalności.

\subsection{Naruszenie zakazu dyskryminacji}

Niedopuszczalność dyskryminacji została uregulowana konstytucyjnie. Zgodnie z art. 32 ust. 2 Konstytucji RP „Nikt nie może być dyskryminowany w życiu politycznym, społecznym lub gospodarczym z jakiejkolwiek przyczyny". W celu doprecyzowania konstytucyjnej zasady zasada niedyskryminowania w zatrudnieniu została wprowadzona do art. $18^{3}$ Kodeksu pracy, w świetle którego „Pracownicy powinni być równo traktowani w zakresie nawiązania i rozwiązania stosunku pracy, warunków zatrudnienia, awansowania oraz dostępu do szkolenia w celu podnoszenia kwalifikacji zawodowych, w szczególności bez względu na płeć, wiek, niepełnosprawność, rasę, religię, narodowość, przekonania polityczne, przynależność związkową, pochodzenie etniczne, wyznanie, orientację seksualna, a także bez względu na zatrudnienie na czas określony lub nieokreślony albo w pełnym lub w niepełnym wymiarze czasu pracy". Katalog przyczyn dyskryminacji ze względu na zwrot w szczególności jest otwarty.

Zgodnie z orzecznictwem Sądu Najwyższego: „Dyskryminacja jest nieusprawiedliwione obiektywnymi powodami gorsze traktowanie pracownika ze względu na niezwiązane z wykonywana pracą cechy lub właściwości dotyczące go osobiście i istotne ze społecznego punktu widzenia,

23. Rozporządzenie Parlamentu Europejskiego i Rady (UE) 2016/679 z dnia 27 kwietnia 2016 r. w sprawie ochrony osób fizycznych w związku z przetwarzaniem danych osobowych i w sprawie swobodnego przepływu takich danych oraz uchylenia dyrektywy 95/46/WE (ogólne rozporządzenie o ochronie danych; Dz. U. UE. L. 2016, nr 119, s. 1 z późn. zm., dalej: RODO). 
przykładowo wymienione w art. $18^{3 a} \S 1$ k.p., bądź ze względu na zatrudnienie na czas określony lub nieokreślony albo w pełnym lub niepełnym wymiarze czasu pracy”. Nie ulega wạtpliwości, że dyskryminacja pracowników ze względu na kryterium majątkowe - które brane jest pod uwagę na podstawie pkt. 3.2.1.2.4.1. Metodyki - jest niedozwolona. Przemawia za tym wskazanie kryterium majatkowego wprost w art. 21 ust. 1 KPP UE, zgodnie z którym: „Zakazana jest wszelka dyskryminacja w szczególności ze względu na płeć, rasę, kolor skóry, pochodzenie etniczne lub społeczne, cechy genetyczne, język, religię lub przekonania, poglądy polityczne lub wszelkie inne poglądy, przynależność do mniejszości narodowej, majątek, urodzenie, niepełnosprawność, wiek lub orientację seksualna".

\subsection{Ograniczenie wolności działalności gospodarczej}

Wolność działalności gospodarczej jest jednym z filarów społecznej gospodarki rynkowej, będacej podstawą ustroju gospodarczego RP. Zgodnie z art. 20 Konstytucji RP „Społeczna gospodarka rynkowa oparta na wolności działalności gospodarczej, własności prywatnej oraz solidarności, dialogu i współpracy partnerów społecznych stanowi podstawę ustroju gospodarczego Rzeczypospolitej Polskiej”. Z wolności działalności gospodarczej wynika kompetencja do prowadzenia działalności według własnego uznania.

Działalność ubezpieczeniowa należy do działalności regulowanej i nadzorowanej przez KNF, przez co podlega szczególnym wymaganiom. Jednakże - jak już wspomniano - jest to działalność, której podstawowym celem jest osiaganie zysku. Należy podkreślić, że zakład ubezpieczeń może być prowadzony w formie spółki akcyjnej, a zatem działalność ubezpieczeniowa wykonywana jest przez podmiot, który posiada konstytutywne cechy spółki prawa handlowego, a dokładniej spółki akcyjnej nastawionej na osiaganie zysku (budowanie wartości dla akcjonariuszy). Cel zarobkowy zakładu ubezpieczeń jako spółki akcyjnej uwidacznia się w sposób szczególny w przypadku zakładów ubezpieczeń będących spółkami giełdowymi, których zarządy, działając jako organ, zawarły swoistą umowę z inwestorami, że w zamian za środki pozyskiwane w ofercie publicznej zakład ubezpieczeń będzie zarządzany w sposób, który zmierza do budowania wartości jego akcji. Wyjatkowość zakładu ubezpieczeń wynika z branży, w której podmiot ten działa. Ingerencja organu nadzoru w tę działalność musi zatem również wynikać z założeń (i być ograniczona przez założenia], którym podporządkowana jest cała branża, a także specyficzne zasady działalności ubezpieczeniowej, polegającej na przyjmowaniu na siebie ryzyka negatywnych ekonomicznych skutków zdarzeń ubezpieczeniowych za uprzednim wynagrodzeniem, które nie podlega zwróceniu w przypadku niewystapienia zdarzenia ubezpieczeniowego.

Ingerencja KNF w działalność zakładu ubezpieczeń, w tym w obsadę stanowisk kierowniczych, musi zatem ograniczać się do podejmowania działań niewykraczających poza ramy uznania administracyjnego limitowanego celem sprawowania czynności nadzorczych, tj. postulatem zapewnienia bezpieczeństwa m.in. ubezpieczających, ubezpieczonych i uprawnionych z umów ubezpieczenia, o przestrzeganie którego dba m.in. rada nadzorcza zakładu ubezpieczeń. Ingerencja regulatora w działalność ubezpieczeniową musi być zatem wyważona w sposób szczególny i dążyć do pogodzenia celu nadzoru z celem funkcjonowania zakładu ubezpieczeń jako spółki akcyjnej.

Członkowie organów są wybierani przez akcjonariuszy (bezpośrednio - w przypadku członków rady nadzorczej - lub pośrednio - w przypadku członków zarządu, którzy wybierani są przez radę nadzorczą pochodzącą z wyboru akcjonariuszy) i to właśnie akcjonariusze w ramach prowadzonej 
działalności i podjętego ryzyka gospodarczego powinni mieć możliwość swobodnego kształtowania składu osobowego organów. Kryteria określone w Metodyce ograniczają wolność działalności gospodarczej akcjonariuszy. Liczba kryteriów oraz ich subiektywny, ocenny, a wręcz arbitralny charakter rodzą ryzyko utraty kontroli nad swobodą wyboru składu organów instytucji finansowej przez organ właścicielski. Przewidziane kryteria są tak liczne i dowolne, że w praktyce mogłoby się okazać, że znalezienie odpowiedniego kandydata, który zostanie zaakceptowany przez KNF, jest niemożliwe. Warto mieć także na uwadze, że analogiczne kryteria nie są przyjmowane podczas obsadzania kluczowych stanowisk administracji centralnej, a proces - ten z uwagi na interes publiczny oraz wysoki poziom odpowiedzialności (wymagajacy najwyższych kompetencji) - powinien być bardziej sformalizowany i wymagający w stosunku do kandydatów.

\subsection{Wieloznaczne kryteria}

Wieloznaczność jest cechą naturalna języka, którym się posługujemy. Wieloznaczny tekst prawny stanowi wyraz porażki prawodawcy (zawinionej lub nieuniknionej, ponieważ słowo często zaczyna żyć własnym życiem, a jego znaczenie zmienia się w zależności od kontekstu, czasu i okoliczności zastosowania). Użycie zwrotu niedookreślonego w tekście prawnym stanowi natomiast wyraz świadomej decyzji twórcy tekstu, który w ten sposób dąży do zachowania niezbędnej elastyczności normy prawnej ze względu na naturę zjawiska poddanego regulacji. Chodzi o zagwarantowanie możności zastosowania normy do wielu zróżnicowanych stanów faktycznych, których nie da się skatalogować (sformatować). Technika zwrotu niedookreślonego w tekście prawnym jest przykładem zrozumienia przez prawodawcę angielskiego powiedzenia one size does not fit all.

Zwrot niedookreślony wymaga „szycia na miarę” konkretnego przypadku. Konstrukcja ta wywołuje u wielu w istocie dyskomfort poznawczy, ponieważ zmusza do wysiłku i, co trudniejsze, przyjęcia odpowiedzialności za wynik konkretyzacji tego zwrotu. Zwrot niedookreślony zawsze stawia wyżej poprzeczkę w procesie stosowania prawa, ponieważ wymaga odczytania jego treści, czyli zdiagnozowania rzeczywistego stanu rzeczy, a nie prostego odczytania przepisu. Zwrot niedookreślony wiąże się oczywiście z pewnym luzem decyzyjnym stosującego prawo. Nie należy tego jednak mylić z dowolnością oceny.

Jednakże kryteria użyte w Metodyce pozwalają na dowolną ocenę, dlatego też nie są zwrotami niedookreślonymi, lecz są zwrotami wieloznacznymi. Zwroty takie, jak postępowanie w sposób przejrzysty i otwarty, zła sytuacja finansowa, cechy osobiste, a także standardy etyczne czy odwaga, asertywność, umiejętność stawiania właściwych pytań, konstruktywne kwestionowanie decyzji, powoduja, że postępowanie dowodowe w przypadku wydania odmownej decyzji przez KNF jest niemożliwe do przeprowadzenia. Kryteria te są całkowicie niemierzalne i pozwalają na dowolną ocenę, a zatem nie jest możliwa kontrola uznania administracyjnego, mająca być gwarantem zasady legalizmu i praworządności.

Ponadto, akcjonariusze lub rada nadzorcza, dokonując wyboru, nie mają jasnych i jednoznacznych wytycznych co do profilu kandydata, które pomogłyby im przewidzieć zatwierdzenie kandydatury (lub brak zakwestionowania obecnego członka organu) przez nadzorcę. Zdaniem KNF, Metodyka zapewnia jednakowe i jasne „reguły gry” (level playing field) oraz zwiększa transparentność i przewidywalność procesu oceny, jednak użycie w jej zapisach kryteriów niemierzalnych, sprzyjających dowolności stoi w sprzeczności z tymi deklaracjami. 


\subsection{Naruszenie zasady legalizmu i praworządności}

Poprzez wprowadzenie do Metodyki kryteriów, które stoją w sprzeczności z prawem do prywatności, zakazem dyskryminacji, wolnością działalności gospodarczej (sprzeczności te nie znajduja uzasadnienia w zasadzie proporcjonalności], doszło do naruszenia zasady legalizmu i praworządności. Za przyjęciem takiego osądu przemawia również zastosowanie wieloznacznych zwrotów, które utrudniają, a wręcz uniemożliwiają kontrolę sądową uznania administracyjnego i sprzyjają jednocześnie przekroczeniu granic uznania administracyjnego.

\subsection{Ocena przykładowych postanowień Metodyki}

Poniższa tabela zawiera ocenę przykładowych postanowień Metodyki.

\begin{tabular}{|c|c|c|}
\hline Pkt Metodyki & Treść & Ocena \\
\hline 3.2.1.2.3.1. & $\begin{array}{l}\text { W pojęciu reputacji mieści się } \\
\text { nieposzlakowana opinia, cechy osobiste, } \\
\text { a także standardy etyczne, w tym } \\
\text { dotychczasowe postępowanie. Należy } \\
\text { zauważyć, że jest to przesłanka kluczowa } \\
\text { w procesie oceny rękojmi. }\end{array}$ & $\begin{array}{l}\text { Kryterium jest niejasne, stricte subiektywne, } \\
\text { całkowicie niemierzalne i pozwala } \\
\text { na dowolną ocenę, a zatem w przypadku } \\
\text { podważenia przez KNF spełnienia kryterium } \\
\text { nie jest możliwa efektywna kontrola uznania } \\
\text { administracyjnego, mająca być gwarantem } \\
\text { zasady legalizmu i praworządności. }\end{array}$ \\
\hline 3.2.1.2.3.2 & $\begin{array}{l}\text { Przy ocenie reputacji, uczciwości i etyczności } \\
\text { należy wziać pod uwagę co najmniej } \\
\text { następujące okoliczności: dowody } \\
\text { wskazujące na to, że osoba nie postępowała } \\
\text { w sposób przejrzysty i otwarty lub nie } \\
\text { współpracowała w kontaktach z właściwymi } \\
\text { organami [...]. }\end{array}$ & $\begin{array}{l}\text { Kryterium jest niejasne, stricte subiektywne, } \\
\text { całkowicie niemierzalne i pozwala } \\
\text { na dowolną ocenę, a zatem w przypadku } \\
\text { podważenia przez KNF spełnienia kryterium } \\
\text { nie jest możliwa efektywna kontrola uznania } \\
\text { administracyjnego, majaca być gwarantem } \\
\text { zasady legalizmu i praworządności. }\end{array}$ \\
\hline 3.2.1.2.4.1. & $\begin{array}{l}\text { Udział w przedsięwzięciach gospodarczych, } \\
\text { które skutkowały niewypłacalnością, } \\
\text { upadłością lub trudna sytuacją finansową, } \\
\text { budzi wątpliwości co do prawidłowego } \\
\text { zarządzania instytucją nadzorowana. } \\
\text { Ponadto zła sytuacja finansowa osoby } \\
\text { podlegającej ocenie może również } \\
\text { negatywnie wpływać na jej niezależność } \\
\text { osądu. }\end{array}$ & $\begin{array}{l}\text { Przyjęte kryterium majatkowe jest } \\
\text { przede wszystkim naruszeniem prawa } \\
\text { do prywatności, ponieważ aby stwierdzić } \\
\text { zła sytuację finansową, należy najpierw } \\
\text { zasięgnać informacji o stanie majątkowym } \\
\text { danej osoby. Wymóg sporządzenia } \\
\text { oświadczenia majątkowego pozwalającego } \\
\text { poznać sytuację finansową musi wynikać } \\
\text { wprost z obowiazujących przepisów } \\
\text { prawa. Obowiązek taki obecnie spoczywa } \\
\text { np. na senatorach, posłach, sędziach, } \\
\text { prokuratorach. Co do zasady, są to osoby } \\
\text { będace funkcjonariuszami publicznymi, } \\
\text { nie należą natomiast do nich członkowie } \\
\text { organów zakładów ubezpieczeń. } \\
\text { Ograniczenie prawa do prywatności nie } \\
\text { znajduje w tym zakresie uzasadnienia } \\
\text { w zasadzie proporcjonalności. } \\
\text { Ponadto, „zła sytuacja finansowa” jest } \\
\text { kolejnym pojęciem niemierzalnym, } \\
\text { pozwalającym na dowolną ocenę. Nie } \\
\text { jest jasne, w którym momencie człowiek } \\
\text { przestaje należeć do kategorii osób o złej }\end{array}$ \\
\hline
\end{tabular}




\begin{tabular}{|c|c|c|}
\hline & & $\begin{array}{l}\text { sytuacji finansowej. Kryterium to świadczy } \\
\text { także o dyskryminacji mniej zamożnych } \\
\text { kandydatów lub aktualnych członków } \\
\text { organów, a jego założenie jest błędne. Osoby } \\
\text { o wysokim statusie majątkowym mogą być } \\
\text { tak samo podatne na zależność osadu jak } \\
\text { osoby o „złej sytuacji finansowej”, dlatego też } \\
\text { kryterium to jest bezcelowe. }\end{array}$ \\
\hline 3.2.1.2.4.3. & $\begin{array}{l}\text { W sektorze ubezpieczeniowym ocena } \\
\text { reputacji osoby podlegającej ocenie } \\
\text { obejmuje jej sytuację finansową, Ocena } \\
\text { dotyczy zarówno obszaru prywatnego, jak } \\
\text { i zawodowego. } \\
\text { W zakresie sytuacji finansowej w procesie } \\
\text { oceny uwzględnia się poniższe okoliczności: } \\
\text { [ ... o ogłoszenie upadłości podmiotu, } \\
\text { w którym osoba objęta oceną pełni lub } \\
\text { pełniła funkcję w zarządzie lub radzie } \\
\text { nadzorczej, lub oddalenie wniosku } \\
\text { o ogłoszenie upadłości ze względu na to, } \\
\text { że majatek dłużnika nie wystarczał } \\
\text { na pokrycie kosztów postępowania, } \\
\text { [....] występowanie jako strona } \\
\text { w postępowaniach sądowych, których wynik } \\
\text { mógł mieć negatywny wpływ na sytuację } \\
\text { finansową osoby podlegającej ocenie [... ]. }\end{array}$ & $\begin{array}{l}\text { Zaproponowane przez KNF kryterium } \\
\text { wymaga doprecyzowania. Należy zaznaczyć, } \\
\text { że upadłość sama w sobie nie jest } \\
\text { zjawiskiem negatywnym, przesądzającym } \\
\text { o nieumiejętności zarządzania. Nie musi } \\
\text { być ona efektem błędu w zarządzaniu, } \\
\text { tylko efektem czynników zewnętrznych } \\
\text { (przykładowo upadłość związana } \\
\text { ze spadkiem popytu na określony towar } \\
\text { spowodowany rozwojem technologicznym } \\
\text { lub upadłość podmiotu, którego głównym } \\
\text { dostawcą był podmiot pochodzący } \\
\text { z Iranu, z którym ograniczono możliwość } \\
\text { handlu z uwagi na nałożone na Iran } \\
\text { sankcje międzynarodowe). Kryterium } \\
\text { powinno uwzględniać czas pełnienia } \\
\text { funkcji w upadłym podmiocie, a także } \\
\text { prawidłowość podjętych czynności [np. czy } \\
\text { doszło do dokonania przez upadłego } \\
\text { bezskutecznych czynności, o których mowa } \\
\text { w art. 12? Prawa upadłościowegou. } \\
\text { W odniesieniu do występowania jako strona } \\
\text { w postępowaniach sądowych, których wynik } \\
\text { mógł mieć negatywny wpływ na sytuację } \\
\text { finansową osoby podlegającej ocenie, należy } \\
\text { zauważyć, że nie doprecyzowano, czy } \\
\text { sam fakt wyrządzenia szkody w majątku } \\
\text { wystarczy do uznania negatywnego wpływu } \\
\text { na ocenę kandydata. Ponadto, postępowanie } \\
\text { sądowe może mieć różne podłoże. } \\
\text { Przykładowo: do negatywnego wpływu } \\
\text { na sytuację finansową osoby może wpłynać } \\
\text { przegrane postępowanie o uznanie klauzuli } \\
\text { umownej za niedozwoloną lub nałożenie } \\
\text { na osobę obowiązku alimentacyjnego. }\end{array}$ \\
\hline 3.2.1.2.5.1. & $\begin{array}{l}\text { Ocena niezależności osądu obejmuje } \\
\text { kwestie związane z potencjalnym lub już } \\
\text { występujacym konfliktem interesów, a także } \\
\text { cechy i umiejętności behawioralne osób } \\
\text { podlegających ocenie, przejawiające się w ich } \\
\text { zachowaniu, takie jak odwaga, asertywność, } \\
\text { umiejętność stawiania właściwych pytań, } \\
\text { konstruktywne kwestionowanie decyzji. }\end{array}$ & $\begin{array}{l}\text { Wymagane przez KNF cechy stanowią } \\
\text { kryterium, które jest niejasne, stricte } \\
\text { subiektywne, całkowicie niemierzalne } \\
\text { i pozwala na dowolną ocenę, a zatem } \\
\text { w przypadku podważenia przez } \\
\text { KNF spełnienia kryterium nie jest } \\
\text { możliwa efektywna kontrola uznania } \\
\text { administracyjnego, mająca być gwarantem } \\
\text { zasady legalizmu i praworządności. }\end{array}$ \\
\hline
\end{tabular}

24. Ustawa z dnia 28 lutego 2003 r. - Prawo upadłościowe (tekst jedn. Dz. U. 2020, poz. 1228). 
Wątpliwości budzą także wprowadzone do Metodyki kryteria stanowiące ekstrakt z Wytycznych $E_{B A}^{25}$ i odnoszące się do sektora bankowego (lub analogiczne kryteria wynikające z wytycznych EIOPA odnoszące się do sektora ubezpieczeniowego ${ }^{26}$ ]. Biorąc pod uwagę fakt, że KNF może zdecydować, czy stosuje się do Wytycznych EBA ${ }^{27}$, przed wprowadzeniem do Metodyki wytyczne te powinny zostać poddane krytycznej ocenie, która zapobiegłaby powieleniu elementów dyskusyjnych. Jako przykład można podać kryteria dotyczące cech behawioralnych wymaganych w sektorze bankowym. Są one zbliżone do ocenionego powyżej kryterium z pkt. 3.2.1.2.5.1. Metodyki, jednak zostały rozszerzone.

W pkt. 3.2.1.2.5.4. Metodyki w zakresie oceny niezależności osądu wymaga się uwzględnienia następujących cech charakteru osoby podlegającej ocenie, wynikających z pkt 82 lit. a Wytycznych EBA:

- odwagi, przekonania i siły, aby w sposób skuteczny oceniać i kwestionować decyzje proponowane przez innych członków organu;

- zdolności zadawania właściwych pytań członkom zarządu;

- zdolności do przeciwstawienia się „grupowemu myśleniu”.

Przedstawione kryteria behawioralne dotyczą zidentyfikowanej przez Warrena Buffetta „atmosfery sali posiedzeń" - atmosferze tej nie da się skutecznie zapobiec, ponieważ jest ona wpisana w naturę organu kolegialnego ${ }^{28}$, a pożądanych cech nie można obiektywnie ocenić oraz zmierzyć, a następnie dokonać kontroli oceny. W związku z tym wprowadzanie ich do Metodyki budzi wątpliwości.

\section{Podsumowanie}

Wszelkie działania KNF, będącego „emanacja państwa”, muszą pozostawać w zgodności z Konstytucją RP i zasadami z niej wynikającymi. Organy władzy publicznej działają na podstawie i w granicach prawa, przez co KNF może czynić jedynie to na co wprost zezwala prawo. Zasada legalizmu oraz praworządności służy temu, aby każdy, kto miał władcze możliwości ingerencji w sytuację prawną

25. Wytyczne Europejskiego Urzędu Nadzoru Bankowego i Europejskiego Urzędu Nadzoru Giełd i Papierów Wartościowych w sprawie oceny odpowiedniości członków organu zarządzającego i osób pełniących najważniejsze funkcje, ESMA71-99-598 EBA/GL/2017/12, 21/03/2018 (dalej: Wytyczne EBA).

26. EIOPA Supervisory Handbook Chapter on Supervision of the Administrative Management or Supervisory Body (AMSB) oraz wytyczne dotyczące systemu zarządzania EIOPA-BoS-14/253 PL.

27. Stosownie do pkt. 1.3. Wytycznych EBA: „Zgodnie z art. 16 ust. 3 rozporządzenia (UE) nr 1093/2010 oraz art. 16 ust. 3 rozporządzenia (UE) nr 1095/2010, właściwe organy poinformują EUNB i ESMA, czy stosują się lub czy zamierzają zastosować się do niniejszych wytycznych, bądź o powodach niestosowania się do wytycznych w terminie do 21.05.2018. W przypadku braku powiadomienia w tym terminie EUNB i ESMA uznaja, że właściwy organ nie stosuje się do niniejszych wytycznych. Powiadomienia będą przesyłane za pomoca formularza dostępnego na portalu internetowym EUNB na adres compliance@eba.europa.eu, powołując się na numer „EBA/GL/2017/12”, oraz formularza dostępnego na portalu internetowym ESMA na adres managementbody.guidelines@esma.europa.eu, powołując się na numer [...]. Powiadomienia przekazuja osoby odpowiednio upoważnione do informowania o stosowaniu się do wytycznych w imieniu właściwego organu. Wszelkie zmiany dotyczące stosowania się do wytycznych należy również zgłaszać do EUNB i ESMA."

28. W. Buffett, "Berkshire Hathaway Annual Shareholder Letter" 2002, s. 16-17, https://www.berkshirehathaway. com/letters/2002pdf.pdf [dostęp: 2.10.2020]. 
drugiej osoby, zrobił z tego pozytywny użytek, nie naruszając jednocześnie obowiązującego prawa. Jednakże, zgodnie z zasada proporcjonalności, nadmierna ingerencja nie jest dozwolona nawet wtedy, gdy dokonywana jest w dobrej wierze.

Oceniając przesłankę dawania rękojmi prowadzenia spraw zakładu w sposób należyty przez członka organu oraz ustalając kryteria jej spełnienia, KNF działa w ramach uznania administracyjnego, co nie oznacza jednak, że KNF ma pełną swobodę i dowolność w tym zakresie. Uznanie administracyjne podlega bowiem kontroli sądowej, ponieważ każda władcza możliwość ingerencji w podmiot prywatny musi podlegać kontroli.

W przypadku ustalania granic uznania administracyjnego należy wziąć pod uwagę wartości wynikajace z całego systemu prawa, w tym cel nadzoru KNF określony w ustawach sektorowych. Do granic tych należy także zasada proporcjonalności.

Poprzez wprowadzenie do Metodyki kryteriów, które stoją w sprzeczności z prawem do prywatności, zakazem dyskryminacji, wolnościa działalności gospodarczej (a sprzeczności te nie znajdują uzasadnienia w zasadzie proporcjonalności], doszło do naruszenia zasady legalizmu i praworzadności. Przemawia za tym także zastosowanie wieloznacznych zwrotów, które utrudniają, a nawet uniemożliwiają kontrolę sądową uznania administracyjnego i sprzyjajajednocześnie przekroczeniu granic uznania administracyjnego.

Zdaniem KNF Metodyka zapewnia jednakowe i jasne „reguły gry” oraz zwiększa transparentność i przewidywalność procesu oceny, jednak w rzeczywistości kryteria wprowadzone przez KNF powoduja, że akcjonariusze lub rada nadzorcza, dokonujące wyboru członka organu, nie maja jasnych i jednoznacznych wytycznych co do profilu kandydata, które pomogłyby im przewidzieć zatwierdzenie kandydatury (lub brak zakwestionowania obecnego członka organu) przez nadzorcę.

W praktyce rady nadzorcze i akcjonariusze moga utracić kontrolę nad doborem kandydatów optymalnych z punktu widzenia właścicielskiego na rzecz KNF. Metodyka wprowadza bowiem kryteria akceptacji oparte na dowolności nadzorcy a nie uznaniowości poddającej się kontroli sądowej. Argument, że obecni urzędnicy KNF będę czynić właściwy użytek ze skonstruowanej przez nich Metodyki, nie przekonuje z dwóch powodów. Po pierwsze, celem Metodyki powinno być zapewnienie przewidywalności stanowiska KNF wobec kandydata wybranego przez organ właścicielski instytucji finansowej, a tego Metodyka nie zapewnia. Po drugie, rządy prawa różni od rządów ludzi uniezależnienie podejmowania decyzji o charakterze władczym ingerującym w prawa i wolności innych gwarantowanych konstytucyjnie od dość ryzykownej przesłanki (nieznajdującej potwierdzenia w historii], iż korzystający z władzy czynią to zawsze rozsądnie i rzetelnie. Wszak istotę rządów prawa i wynikajaccej z niej zasady legalizmu władz publicznych ilustruje powiedzenie „Wolimy już być spętani przez prawa, niż żeby spętane były prawa”. Nie chodzi zatem o to, czy obecni urzędnicy KNF będą z umiarem i roztropnością korzystać z Metodyki, ale o eliminację systemowego ryzyka, iż „dzisiaj” lub „jutro” pojawi się ów nieroztropny, pozbawiony umiaru i nierzetelny urzędnik. Przy czytaniu Metodyki nasuwa się pytanie: „0 co chodzi; o margines swobody czy swobodę marginesu?". Metodyka zdaje się, niestety, promować swobodę marginesu.

\section{Wykaz źródeł}

Buffett W., "Berkshire Hathaway Annual Shareholder Letter" 2002, s. 16-17, https://www.berkshirehathaway.com/letters/2002pdf.pdf [dostęp: 2.10.2020]. 
Gronkiewicz-Waltz H., Ewolucja pozycji banku centralnego w świetle zmian w prawie bankowym, „Państwo i Prawo” 1990, nr 6.

Jaroszyński K., [w:] Banasiński C., Glibowski K., Gronkiewicz-Waltz H., Jaroszyński K., Kaszubski

R., Wierzbowski M., Prawo gospodarcze. Zagadnienia administracyjnoprawne, LexisNexis, Warszawa 2013.

Jaśkowska M., Uznanie administracyjne w orzecznictwie sqdów administracyjnych, „Zeszyty Naukowe Sądownictwa Administracyjnego" 2010, nr 5-6.

Jaśkowska M., [w:] Instytucje prawa administracyjnego. System Prawa Administracyjnego. Tom 1, Hauser R. [red.], CH Beck, Warszawa 2015.

Nieborak T., Komisja Nadzoru Finansowego jako gwarant stabilności polskiego systemu finansowego, [w:] Prawo wobec wyzwań współczesności. Tom 5, Guzik B., Buchowska N., Wiliński P.

[red.], Wydawnictwo Uniwersytetu im. Adama Mickiewicza, Poznań 2008.

Wajda P., Zgoda Komisji Nadzoru Finansowego na powołanie dwóch członków zarzqdu krajowego zakładu ubezpieczeń lub krajowego zakładu reasekuracji - wybrane aspekty, „Wiadomości Ubezpieczeniowe" 2016, nr 1.

Zimmermann J., Prawo administracyjne, Wolters Kluwer, Warszawa 2012.

\section{Assessment of the criteria adopted by the Polish Financial Supervision Authority in the Methodology for assessing the suitability of the members of the bodies of supervised entities 2020}

The methodology presented by the Polish Financial Supervision Authority for assessing the suitability of the members of the bodies of supervised entities was to present objective assessment criteria, based on the legal regulations which are followed by the Polish Financial Supervision Authority and the Office of the Polish Financial Supervision Authority. The number of criteria and their subjective, evaluative and even arbitrary and immeasurable character makes the methodology may become a fiction in practice and an instrument which is not useful for a reliable assessment of a candidate for membership in the bodies of a financial institution. There is a risk that supervisory boards or shareholders will pretend to apply the Methodology in practice and the KNF will pretend to be able to verify the candidate's assessment in this way. The methodology does not provide clear and measurable guidelines for the candidate's profile that would help predict whether the candidate will be accepted by the supervisor. The methodology resembles more the criteria prepared by the so called headhunter or HR department (of highly diverse and often questionable usefulness] than the criteria for legal assessment of whether a candidate guarantees prudent and stable management of a financial institution. In practice, supervisory boards and shareholders may lose control over the selection of optimal candidates from the ownership point of view to the KNF. The methodology introduces acceptance criteria based on the discretion of the supervisor and not on the discretionary nature of the candidate subject to judicial review. This violates the constitutional principle of economic freedom. Moreover, the analysis of the provisions of the Methodology leads to the conclusion that some of the criteria are in conflict with constitutional human rights and freedoms. These contradictions are not justified by the principle of proportionality. This means that the Methodology violates the principles of legalism and the rule of law. 
Keywords: Methodology for assessing the suitability of members of the bodies of supervised entities, the guarantee of conducting the enterprise's affairs properly, administrative discretion and latitude, the rule of law, the principle of legalism.

PROF. DR HAB. MICHAŁ ROMANOWSKI - Instytut Prawa Cywilnego, Wydział Prawa i Administracji, Uniwersytet Warszawski; w latach 2006-2015 (do chwili likwidacji) członek Komisji Kodyfikacyjnej Prawa Cywilnego, przewodniczący zespołu ds. umowy ubezpieczenia; wspólnik w kancelarii Romanowski i Wspólnicy.

email:m.romanowski@romanowski.eu

KATARZYNA ZARZYCKA - aplikantka adwokacka w kancelarii Romanowski i Wspólnicy, laureatka ogólnopolskiego konkursu „Przegladu Prawa Handlowego” na najlepsze prace magisterskie z prawa handlowego za pracę pt. Corporate governance oczami Warrena Buffeta napisaną na Wydziale Prawa i Administracji Uniwersytetu Warszawskiego pod kierunkiem prof. Michała Romanowskiego. email:k.zarzycka@romanowski.eu 